\title{
KARAKTERISTIK NASKAH DRAMA SERIAL BERTEMA CINTA TANAH AIR KARYA SISWA EKTRAKULIKULER TEATER SMAN 4 MALANG
}

\author{
Defi Permatasari \& Yuni Pratiwi \\ Universitas Negeri Malang \\ E-mail: defipermatasari96@gmail.com,yuni.pratiwi.fs@um.ac.id
}

\begin{abstract}
Abstrak
Salah satu kompetensi yang dikemban gkan dalam kegiatan ekstrakurikuler teater SMA Negeri 4 Kota Malang a dalah komptensi menulis na skah drama serial. Tema yang dipilih dalam pelatihan penulisa n naskah drama serial pada tahun 2020 a dalah cinta tanah air. Halini dipandang penting karema ra sa cinta tanah air perlu ditanamkan sebagai sa lah satu karakter utama siswa Indonesia . Penelitian inibertujuan untuk mendeskripsikan karakter naska drama serialkarya siswa dari a spek tokoh dan penokohan, plot, latar, tema, dialog, petunjuk laku. Penelitian ini menggunakan pendekatan kualitatif dengan metode analisis strukturnaskah drama. Su mber data penelitian berupa dokumen karya siswa dan hasil wa wancara. Hasil daripen elitian m enunjukkan bah wa kara kteristik naskah drama mencakup: (1) tokoh dan pe nokohan dalam naskah drama seria 1 mencakup dua halyaitu, pengarang sebagai tokoh utamadan pengarang sebagai tokoh pembantu. (2) plot yang digu nakan terdapat tiga kategori yaitu, sumber konflik, keterlibatan tokoh dan konflik, dan kelengkapan plot. (3) lataryang digunakan a dalah lingkun gan sekolah dan rumah seba gai la tar ceita. (4) tema y ang digunakan adalah cinta tanah air dengan subtema pendidikan dan budaya. (5) dia log yang digunakan a dalah dialog umum dengan bahasa sehari-hari. (6) petu njuk laku y ang digunakan a dalah petunjuk lakuan tokoh.
\end{abstract}

Kata Kunci: Naskah drama serial, pendidikan karakter, ekstrakulikuler teater.

\section{Abstract}

One of the competencies developed in the extracurricular activities of theater at SMAN4 Malang is the competence in writing serial drama scripts. The theme chosen in the drama series script writing training in 2020 is love for the country. This is considered important because the love of the country needs to be instilled as one of the main characters of Indonesian students. This study aims to analyze the character and characterization, plot, setting, theme, dialogue, and action instructions. This study uses a qualitative approach with the method of structural analysis of drama scripts. Sources of research data in the form of studentwork documents and interview results. The results of the study indicate that the characteristics of the drama script include: (1) characters and characterizations in a serial drama script include two things, namely, the author as the main character and the author as the supporting character.(2) the plot used con sists of three categories, namely, sources of conflict, involvement of figures and conflicts, and completeness of the plot. (3) the setting used is the school and home environment as the background for the story. (4) the theme used is love for the country with the sub-theme of education and culture. (5) the dialogue used is general in everyday language. (6) the guidelines for the behavior used are the guidelines for the behavior of the characters.

Keywords: Serial drama scripts, character education, theater extracurricular activities.

\section{PENDAHULUAN}

Naskah drama adalah karangan cerita yang berisi tokoh dan dialog yang akan dipentaskan di atas panggung. Dalam naskah drama memuat nama tokoh, dialog para tokoh dan sebuah gambaran tentang keadaan panggung yang diperlukan. Solihuddin (2013:22) menyatakan bahwa ciri khusus yang dimilik oleh naskah drama terdapat pada dialog yang akan membedakan dengan karya sastra yang lain. Naskah drama menggambarkan konflik kehidupan dan watak manusia yang dipentaskan di atas panggung dalam beberapa babak. Konflik yang ada dalam naskah drama digali dari kehidupan sehari-hari manusia. Banyak sekali naskah drama yang ditulis berdasarkan kisah kehidupan yang benarbenar terjadi. Priatno (2010:20) menyatakan bahwa cerita yang disajikan kepada pembaca merupakan sebuah peristiwa yang imajiner 
dengan jalan cerita yang sepenuhnya menjadi hak pengarang.

Naskah drama serial merupakan sekumpulan naskah drama yang ditulis dengan tema dan alur cerita yang berkesinambungan dengan berinduk pada tema utama. Naskah drama serial karya siswa bertema "Cinta Tanah Air" bertujuan untuk memberikan penguatan pendidikan karakter kepada remaja sebagai generasi penurus bangsa untuk mencintai tanah air. Dengan adanya naska drama serial ini bisa menanamkan sifat cinta tanah terutama pada lingkungan pendidikan. Dalam sebuah karya sastra terdapat dua unsur pembangun cerita, yaitu: unsur ekstrinsik dan intrinsik. Dalam pembelajaran menulis naskah drama unsur pembangun cerita yang digunakan adalah unsur intrinsik. Unsur intrinsik adalah unsur yang ada dalam batang tubuh suatu karya sastra. Unsur tersebut antara lain, tokoh dan penokohan, plot, tema, setting atau latar, dialog, dan petunjuk laku.

Unsur pertama dalam naskah drama adalah tokoh dan penokohan. Tokoh melengkapi sebuah naskah drama. Tokoh-tokoh dalam naskah drama digambarkan dengan watak yang berbeda untuk memperkuat isi cerita. Yonny (2014:35) menyatakan bahwa penokohan adalah penciptaan citra tokoh dalam cerita. Penciptaan tokoh dalam cerita harus tampak hidup dan nyata agar pembaca bisa merasakan kehadirannya. Karakter yang dibuat harus memiliki kekuatan tersendiri agar mempunyai dari tarik bagi pembaca. Menurut Yudiaryani (2007:08) ada tiga dimensi ciri-ciri yang melekat pada tokoh, pertama: dimensi fisiologis, yaitu ciri fisik yang berhubungan dengan pekerjaan dan kehidupan sosial; kedua, dimensis sosiologis yaitu ciri fisik yang berhubungan dengan pekerjaan dan kehidupan; ketiga, dimensi psikologis yaitu ciriciri kejiwaan tokoh

Unsur kedua dalam naskah drama adalah alur. Penggambaran isi dalam sebuah naskah drama berdasarkan urutan peristiwa. Alur/plot merupakan susunan peristiwa dari awal sampai akhir yang terdapat konflik antara dua tokoh yang berlawanan. Unsur-unsur yang terdapat dalam alur atau plot meliputi: perkenalan para tokoh beserta dengan watak masing-masing, komplikasi yang berisi pertikaian tokoh, klimak dari cerita, antiklimaks, dan keputusan di akhir cerita. Noorfitriana (2016:13) menyatakan bahwa ada lima jalinan konflik dalam plot naskah drama, yaitu: (1) pelukisan awal cerita, (2) pertikaian awal, (3) titik puncak cerita, (4) penyelesaian, (5) keputusan.

Unsur ketiga yang terdapat dalam sebuah naskah drama adalah tema. Tema merupakan ide dasar yang digunakan sebagai landasan lakon drama. Tema dalam naskah drama merujuk pada sesuatu yang menjadi persoalan pokok yang ingin diungkapkan oleh penulis naskah. Lutter (2010:41) menyatakan bahwa hal yang paling mendasar dalam sebuah karangan yang ingin disampaikan oleh pengarang adalah tema cerita. Pemilihan tema dalam menulis naskah drama bersifat umum berkaitan dengan aspek kehidupan di sekitar kita. Tema pada umumnya cenderung abstrak tidak di ungkapkan secara langsung oleh penulis hanya bisa ditunjukkan dengan bukti atau alasan yang terdapat dalam cerita

Unsur yang harus ada dalam naskah drama. Munculnya konflik dalam naskah drama digambarkan dalam sebuah dialog yang dimunculkan oleh para tokoh. Penyusunan dialog dilakukan dengan memerhatikan pembicaraan tokoh-tokoh dalam kehidupan sehari-hari. Dialog menjadi ciri khas dari sebuah naskah drama. Percakapan yang tersusun dalam dioalg harus mendukung karakter tokoh. Menurut Pratiwi dan Siswiyanti (2014:106) dalam naskah drama terdapat tiga dialog yang digunakan, yaitu: (1) dialog umum, (2) dialog dengan ciri khas dialeg tertentu, (3) dialog dalam puisi.

Unsur yang terakhir adalah pentunjuk laku. Petunjuk laku merupakan penjelasan tentang kondisi, perbuatan dan sifat para tokoh. Petunjuk laku dalam naskah drama ditulis di akhir dialog dengan memberikan buka kurang dan tutup kurung sebagai pembeda anatar dialog dan petunjuk laku. Menurut Waluyo (2003: 29) dalam naskah drama teks samping atau petunjuk laku berguna untuk memberikan gambaran tentang suasana, perasaab, gerak tubuh yang dialami dan harus dilakukan oleh aktor. Petunjuk laku berguna untuk memberikan petunjuk teknis tentang suasana, tempat terjadinya peristiwa, emosi tokoh, dan keluar masuknya tokoh saat berada di atas panggung.

Minimnya naskah drama dengan muatan pendidikan karakter khususnya yang bertemakan cinta tanah air menjadikan kegiatan menulis naskah drama di sekolah menjadi wadah yang sangat bagus. Naskah drama serial bertema "Cinta Tanah Air" merupakan sekumpulan naskah drama yang ditulis oleh sekumpulan penulis dengan tema dan alur cerita yang berkesinambungan dengan berinduk pada tema 
utama. Dalam kegiatan ini siswa secara berkelompok menulis naskah drama dengan tema utama "Cinta Tanah Air" yang kemudian dibagi menjadi beberapa subab tema lagi untuk dikembangkan menjadi alur cerita dalam naskah drama. Menulis naskah drama bertema cinta tanah air merupakan salah satu kegiatan membangun pendidikan karakter dalam proses belajar mengajar dengan harapan supaya bisa menumbuhkan rasa cinta tanah air dalam diri siswa.

Pendidikan sebagai suatu kegiatan yang disengaja sebagai upaya untuk membentuk, mengarahkan, dan mengatur manusia sebagaimana yang dicita-citakan bangsa. Karakter menurut Pusat Bahasa Depdiknas adalah bawaan, hati, jiwa, kepribadian, budi pekerti, perilaku, personalitias, sifat, tabiat, dan watak. Pendidikan karakter secara terus menerus dibangun agar bisa menghasilkan generasi yang diharapkan bangsa. Sesuai dengan Kurikulum Tingkat Satuan Pendidikan tahun 2006 (Permendiknas 22 Th 2006 tentang Standar Isi), Seni teater merupakan salah satu aspek dari mata pelajaran seni budaya di sekolah. Berpijak dari peraturan di atas, maka seni teater yang dipelajari di sekolah adalah seni teater dengan latar belakang budaya tertentu.

Minimnya naskah drama dengan muatan pendidikan karakter khususnya yang bertemakan cinta tanah air menjadikan kegiatan menulis naskah drama di sekolah menjadi wadah yang sangat bagus. Naskah drama serial bertema "Cinta Tanah Air" merupakan sekumpulan naskah drama yang ditulis oleh sekumpulan penulis dengan tema dan alur cerita yang berkesinambungan dengan berinduk pada tema utama. Dalam kegiatan ini siswa secara berkelompok menulis naskah drama dengan tema utama "Cinta Tanah Air" yang kemudian dibagi menjadi beberapa subab tema lagi untuk dikembangkan menjadi alur cerita dalam naskah drama. Menulis naskah drama bertema cinta tanah air merupakan salah satu kegiatan membangun pendidikan karakter dalam proses belajar mengajar dengan harapan supaya bisa menumbuhkan rasa cinta tanah air dalam diri siswa.

Ektrakulikuler teater adalah salah satu ektrakulikuler yang banyak diminati di SMAN 4 Malang. Salah satu kegiatan ektrakulikuler teater yang dilakukan di SMAN 4 Malang adalah menulis naskah drama. Menulis naskah drama menjadi kegiatan rutin yang dilakukan oleh semua anggota teater. Hasil dari tulisan naskah drama karya siswa ektrakulikuler teater ini kemudian dikembangkan untuk dijadikan sebagai naskah pementasan. Menulis naskah drama serial merupakan hal yang baru dilakukan oleh siswa ekstrakulikuler teater SMAN 4 Malang terutama dengan menggunakan tema cinta tanah air. Dalam kegiatan menulis naskah drama tersebut dirasa sangat perlu untuk memberikan pendidikan karakter pada semua anggota teater. Salah satu kegiatan pendidikan karakter yang bisa ditanamkan pada anggota teater ektrakulikuler SMAN 4 Malang dengan cara menulis naskah drama serial bertema "Cinta Tanah Air". Dengan menulis naskah drama serial bertema "Cinta Tanah Air" diharapkan semua anggota teater SMAN 4 Malang memiliki karakter yang kuat dan berjati diri baik untuk mencintai tanah air. Pemilihan tema yang sangat khas tersebut sebagai upaya untuk menyiapkan siswa agar bisa bertahan hidup dengan lebih baik di kehidupan yang berkembang dengan sangat cepat di era milenial yang ditandai dengan perkembangan TIK yang sangat pesat. Rasa cinta tanah air perlu ditanamkan pada generasi melenial supaya nilainilai luhur yang terkandung dalam Pancasila tidak akan luntur seiring dengan berkembangnya zaman.

\section{METODE PENELITIAN}

Penelitian ini menggunakan pendekatan kualitatif. Metode penelitian analisis struktur naskah drama dan jenis penelitian ini merupakan penelitian dokumen. Data penelitian tersebut berupa narasi dan dialog naskah drama serial yang berisi unsur-unsur yang akan dianalisis dari karya siswa ektrakulikuler teater SMAN 4 Malang. Unsur-unsur yang akan dianalisis yaitu: tema, alur, tokoh dan penokohan, dialog dan petunjuk laku. Sumber data penelitian ini berupa naskah drama serial secara keseluruhan karya siswa ektrakulikuler teater SMAN 4 Malang. Prosedur pengumpulan data dilakukan dengan mengumpulkan sumber data. Data dikumpulkan dengan menggunakan instrument tabel pengumpulan data. Teknik pengumpulan data dilakukan dengan tiga tahap, yaitu: menganalisis data, klasifikasi data, dan kodifikasi data. Teknik pengumpulan data dilakukan dengan cara memberikan penugasan menulis naskah drama serial dengan tema "Cinta Tanah Air" yang dibagi kedalam beberapa sub bab tema kepada siswa ekstrakulikuler teater. Penugasan menulis naskah drama disesuaikan dengan batasan- 
batasan yang telah ditentukan oleh peneliti dengan tujuan agar data yang diperoleh lebih terfokus. Proses penulisan naskah drama dilakukan dalam kegiatan ektrakulikuker teater.

\section{HASIL DAN PEMBAHASAN \\ Tokoh dan Penokohan}

Karakteristik tokoh dan penokohan dalam naskah drama serial karya siswa teater SMAN 4 Malang mencakup dua hal, yaitu (1) pengarang sebagai tokoh utama dan (2) pengarang sebagai tokoh pembantu. Peran pengarang sebagai tokoh utama berperan sebagai keluarga, teman sekelas, sahabat, tetangga, dan pelatih. Sedangkan peran pengarang sebagai tokoh pendukung berperan sebagai teman sekelas dan saudara dari tokoh utama (bukan pengarang). Tokoh utama akan muncul secara berkelanjutan dari awal serial hingga akhir. Dalam naskah drama serial, tokoh utama dimunculkan secara terus menerus pada seluruh bagian plot. Adapun tokoh pendukung dimunculkan oleh pengarang sesuai dengan kebutuhan cerita, misalnya untuk mengembangkan konflik, menguatkan pesan, dan menguatkan suasana. Hal ini menandakan bahwa pengarang bisa mengurangi atau menambah tokoh pendukung dalam cerita.

Pratiwi dan Siswiyanti (2014:37), menyatakan bahwa munculnya tokoh utama bertujuan untuk memunculkan persoalan masalah, memperumit dan mengatasi masalah yang ada dalam naskah drama. Selaras dengan pernyataan tersebut, tokoh utama yang diperankan oleh diri pengarang sendiri yang berhak menentukan jalan cerita yang dihadapi tokoh dalam naskah drama dan menentukan penyelesaian masalah di akhir cerita. Tokoh utama yang akan menjadi penentu dari akhir cerita yang sudah disusun secara berurutan oleh pengarang. Tokoh-tokoh yang dimunculkan dalam naskah yaitu dengan identitas pengarang menempatkan dirinya sebagai tokoh utama yang memiliki peran sangat dominan dalam naskah drama, dengan posisinya sebagai tokoh yang dominan pengarang dengan leluasa mengembangkan jalan cerita. Pengarang sebagai tokoh utama dibuktikan dengan adanya penggunaan nama pengarang dalam cerita yang berperan sebagai tokoh utama. Penggunaan kata ganti aku atau saya yang digunakan dalam naskah drama menjadi fokus pusat kesadaran dan pusat cerita yang disajikan. Identitas tokoh utama yang dipilih oleh siswa, yaitu: keluarga, teman sekolah, sahabat, buruh, pelatih, dan tetangga.
Dalam naskah drama serial karya siswa, identitas tokoh utama yang banyak digunakan, yaitu teman sekolah dan sahabat.

Karakteristik penokohan dalam naskah drama yang ditulis oleh siswa ditemukan dan dikembangkan menggunakan dua dimensi yaitu, dimensi sosiologi dan psikologi. Pada dimensi sosiologi, pengarang banyak menggambarkan tokoh sebagai seorang pelajar dan sebagai anggota keluarga. Hal ini berdasarkan dalam kehidupan nyata pengarang yang berstatus sebagai seorang pelajar dalam dunia pendidikan dan sebagai seorang anak dalam anggota keluarga. Dimensi psikologi digambarkan dengan psikis dari tokoh dalam menghadapi atau menyelesaikan masalah.

\section{Plot}

Terdapat tiga kategori plot yang digunakan dalam naskah drama serial karya siswa yaitu, sumber konflik yang digunakan, keterlibatan tokoh dan konflik, dan kelengkapan plot yang digunakan. Sumber konflik yang digunakan oleh pengarang bersumber dari pengalaman pribadi orang lain. Pengarang menggunakan sumber konflik dari pengalaman orang lain karena pengarang belum pernah mengalami peristiwa tersebut. Dari peristiwa yang sudah diperoleh, pengarang sebagai penentu jalan cerita memaparkan dan menyelesaikan masalah dengan jelas yang disesuaikan dengan kehidupan sehari-hari agar tampak nyata. Pratiwi dan Siswiyanti (2014:53) menyatakan bahwa permasalahan dalam naskah drama merupakan cerita dalam kehidupan seharihari yang dikemas dalam sebuah naskah drama dengan berbagai tambahan konflik agar lebih menarik. Pada naskah drama karya siswa konflik tokoh terjadi karena adanya pertentangan tokoh utama dengan teman sekelas atau teman sekolahnya. Hal ini sesuai dengan peran pengarang sebagai seorang pelajar dalam kehidupan nyata yang membuat konflik antar teman muncul. Dalam lingkungan sekolah sering terjadi pertentangan atau perbedaan pendapat antar sesama teman yang muncul dari kegiatan berdiskusi maupun dari masalah pertemanan. Dari cara pandang yang berbeda-beda yang dimiliki setiap orang yang pada akhirnya memimbulkan konflik.

Pada kelengkapan plot dalam naskah drama karya siswa ditemukan penggunaan plot yang lengkap. Sebuah naskah drama bisa dinyatakan memiliki alur yang lengkap jika dalam naskah drama terdapat lima tahapan plot, 
yaitu prolog, orientasi, konflik, resolusi, dan epilog. Menurut Satoto (2012:11-12) naskah lakon yang baik memiliki tahapan yang lengkap mulai dari pemaparan cerita, perumitan dalam cerita, klimaks dari masalah yang terjadi, penyelesaian masalah, dan kesimpulan pada akhir cerita. Penggunaan plot lengkap memiliki alur cerita yang runtut dan terdapat sebuah keputusan yang diberikan oleh pengarang di akhir cerita. Adanya tahapan peleraian dalam naskah drama karya siswa membuktikan bahwa naskah drama tersebut memiliki plot yang lengkap. Pengarang memberikan keputusan di akhir cerita untuk menentukan nasib semua tokoh setelah menjalani monflik panjang yang dihadapi dalam naskah drama.

\section{Latar}

Karakteristik latar dalam naskah drama serial bertema cinta tanah air karya siswa ekstrakulikuler teater SMAN 4 Malang, terdapat tiga jenis latar yang digunakan yaitu, latar tempat, latar waktu, dan latar suasana. Dalam naskah drama serial, latar yang digunakan tidak selalu berurutan karena pengarang menggunakan latar yang berbeda pada setiap serialnya sesuai dengan tingkat pemahaman pengarang sendiri. Pada penggunaan latar tempat, banyak ditemukan latar tempat di lingkungan sekolah terutama di dalam kelas. Latar tempat yang dipilih oleh pengarang karena konflik yang dihasilkan berasal dari kelas. Latar tempat dalam naskah drama harus digambarkan secara jelas, bentuk tata letak panggung yang digunakan saat naskah drama akan dipentaskan. Hal ini bertujuan agar ketika naskah drama dipentaskan tidak mengalami kesulitan. Pengarang juga harus menjelaskan secara rinci misalnya menggunakan ruang kelas sebagai setting tempat harus dijelaskan berapa meja kursi yang ada di ruang kelas selain itu terdapat benda apa saja yang digunakan sebagai properti. Dengan seperti itu akan memudahkan pembaca dalam memberikan gambaran suasana tempat yang digunakan. Status tokoh sebagai pelajar menjadi pendukung pengambilan latar kelas yang digunakan oleh pengarang.

Penggunaan latar waktu yang digunakan dalam naskah drama serial karya siswa ekstrakulikuler teater SMAN 4 Malang menggunakan latar waktu pagi hari saat sedang di sekolah. Latar waktu yang digunakan harus masuk akal agar pembaca tidak mengalami kebingungan atau kesulitan dalam memahami cerita. Latar waktu juga berfungsi sebagai lakuan tokoh, misalnya pada saat bel masuk kelas berbunyi tokoh dalam naskah drama tergesa-gesa memasuki kelas karena sudah terlambat. Hal ini menjadi alasan bahwa latar waktu juga menjadi penentu lakuan tokoh dari peristiwa yang dialami. Penggunaan latar waktu pagi dalam naskah drama karya siswa banyak digunakan karena pada saat waktu pagi hari tokoh yang berperan sebagai siswa bertemu dengan temantemannya saat sedang di sekolah. Saat tokoh bertemu dengan teman atau sahabatnya di sekolah banyak cerita atau permasalahan yang akan dibahas oleh tokoh.

Penggunaan latar suasana dalam naskah drama banyak menggunakan suasana bahagia. Menurut Rokhmansyah (2014:39) penggunaan latar suasana dalam cerita berhubungan dengan konflik yang sedang terjadi. Latar suasana juga berhubungan dengan kondisi psikologi tokoh sesuai dengan konflik yang terjadi dalam cerita. Tujuan latar suasana digunakan dalam naskah drama untuk mengikat tokoh dan pembaca agar bisa merasakan emosional pada cerita yang dibangun. Pemilihan latar suasana bahagia dalam naskah drama karya siswa juga diperngaruhi dari sisi psikologi pengarang. Sebagai seorang remaja yang masih mengalami masa pubertasi memiliki perasaan bahagia, ingin disayang, dan ingin diperhatikan mempengaruhi kondisi psikologisnya dalam naskah drama yang ditulis.

\section{Tema}

Terdapat tiga kategori tema dalam naskah drama karya siswa yaitu, subtema, jenis tema, dan tujuan amanat. Dalam kategori subjek tema disimpulkan menjadi dua subjek yaitu tentang budaya dan pendidikan. Subtema dibedakan menjadi dua, yaitu budaya dan pendidikan. Subtema yang banyak digunakan pengarang yaitu subtema pendidikan dengan menggunakan subjek teman sekolah. Hal ini berdasarkan konflik yang dihadapi tokoh dalam cerita banyak terjadi dengan teman sekolah. Kemunculan teman sekolah sebagai subjek tema yang digunakan bertujuan untuk menciptakan konflik dengan tokoh utama. Perbedaan pendapat antara tokoh utama dengan teman sekolah atau sahabatnya mampu menimbulkan konflik dalam cerita.

Jenis tema yang digunakan dalam nask ah drama serial karya siswa menggunakan tema sosial. Dalam penulisan naskah drama serial ini, secara keseluruhan siswa diberi tema cinta tanah air yang dikembangkan dengan menggunakan jenis tema sosial. Pengarang mengekspresikan 
tema cinta tanah air kedalam naskah drama serial dengan cara mengangkat kisah inspiratif yang bisa memotivasi pembaca untuk mencintai tanah air. Dalam naskah drama serial, pengarang banyak menceritakan kisah tokoh yang berprestasi terutama pada bidang olahraga yang mampu mengharumkan nama Indonesia pada setiap pertandingan yang diikuti. Selain mengangkat kisah dari bidang olahraga, ada beberapa naskah yang bercerita tentang budaya nusantara yang harus dilestarikan oleh generasi muda namun, pengarang memiliki keterbatasan dalam mengembangkan tema karena ini merupakan hal baru bagi pengarang. Pesan yang digunakan dalam naskah drama banyak mengandung pesan sosial tentang melestarikan budaya atau menanamkan rasa cinta tanah air.

Tujuan tema yang digunakan dalam naskah drama karya siswa ditujukan kepada pembaca. Penyampaian pesan dalam naskah drama harus dikemas sebaik mungkin agar pada saat pesan tersebut sampai kepada pembaca tidak seperti indroktinasi. Penyampaiaan pesan dalam naskah drama melalui perilaku tokoh atau dialog tokoh. Pengarang harus memiliki teknik penyampaian pesan yang baik agar tujuan tema bisa diterima pembaca sesuai dengan yang diingunkan. Jika teknik penyampaian tidak berfungsi dengan baik maka tujuan tema tidak akan tersampaikan dengan baik pula kepada pembaca.

\section{Dialog}

Karakteristik naskah drama serial karya siswa ekstrakulikuler teater SMAN 4 Malang jenis dialog yang digunakan adalah dialog umum dengan bahasa sehari-hari. Penggunaan bahasa Indonesia dalam dialog tokoh memudahkan pembaca untuk memahami isi dari cerita karena bahasa Indonesia digunakan untuk komunikasi dalam aktivitas sehari-hari. Dalam naskah drama dialog berfungsi untuk menentukan percakapan yang akan ucapkan tokoh dalam menyampaikan alur cerita. Dialog digunakan sebagai sarana untuk mengisyarakatkan situasi sosial yang sedang dialami atau untuk psikologis tertentu. Penggunaan dialog juga berdasarkan latar belakang tempat tinggal pengarang.

Dalam penggunaan bahasa sehari-hari, pengarang juga menyisipkan bahasa dialek daerah dalam naskah drama karya siswa. Beberapa naskah drama menggunakan dialog bahasa sehari-hari dengan menggunkaan unsur dialek daerah Jawa seperti 'iyo', 'nduk', 'yowes' dan lain sebagainya. Penggunaan dialog dalam naskah drama tidak memiliki batasan yang mengikat pengarang sehingga pengarang bebas menggunakan bahasa sehari-hari dengan menyisipkan bahasa dialek daerah atau dialek metropolitan.

Pengarang menyisipkan bahasa dialek daerah Jawa karena tempat tinggal pengarang dengan lingkungan budaya setempat yang mempengaruhi munculnya dialog tersebut dalam naskah drama. Jika disesuaikan dengan latar belakang pengarang yang berada di daerah Malang maka penggunaan bahasa kebalikan yang menjadi ciri khas masyarakat Malang tidak dimunculkan dalam naskah drama karya siswa. Alasan pengarang tidak memasukkan bahasa khas Malangan ke dalam naskah drama karena bahasa yang digunakan sehari-hari untuk berkomunikasi yang palingan mendominasi menggunakan bahasa Indonesia dan bahasa Jawa sedangkan bahasa Malangan hanya digunakan pada saat-saat tertentu.

\section{Petunjuk Laku}

Petunjuk laku yang digunakan dalam naskah drama yaitu petunjuk lakuan tokoh. Petunjuk laku dikelompokkan menjadi dua jenis, yaitu petunjuk lakuan dan petunjuk emosi tokoh. Penggunaan petunjuk lakuan tokoh dalam naskah drama berguna untuk mengarahkan gerak gerik tokoh saat sedang berada di atas panggung. Petunjuk lakuan tokoh mempermudah tokoh untuk bergerak di atas panggung. Hal ini karena gerakan yang dilakukan tokoh untuk memperjelas jalan cerita dalam naskah drama. Dengan adanya petunjuk lakuan tokoh akan sangat membantu tokoh agar tidak terjadi gerakan mati gaya saat di atas panggung. Jika aktor berada dalam kondisi tersebut, maka akan ada kebingungan dengan lakuan yang akan digunakan karena saat sedang berada di atas panggung lakuan tokoh juga akan disorot oleh mata penonton. Petunjuk lakuan tokoh digunakan untuk mempermudah aktor dalam mengatur gerak saat sedang berada di atas panggung, selain itu petunjuk laku juga memberi kemudahan kepada pengarang untuk memberikan gambaran pengarang untuk merangkai adegan para tokoh.

\section{SIMPULAN}

Berdasarkan hasil penelitian dapat disimpulkan bawah karakteristik naskah drama serial karya siswa ekstrakulikuker SMAN 4 Malang dari segi karakteristik tokoh yang digunakan ditemukan 
bahwa pengarang berperan sebagai tokoh utama. Pengarang memiliki keterbatasan dalam mengembangkan tokoh lain pada naskah drama. Tokoh lain yang digunakan oleh pengarang merupakan tokoh-tokoh yang terdapat pada kehidupan nyata pengarang. Pengarang masih belum bisa mengeksplorasi penggunaan tokoh dengan lebih luas lagi. Hal ini dipengaruhi oleh kehidupan pengarang sebagai seorang pelajar sehingga tokoh yang bisa dikembangkan hanya seputar orang-orang yang berada di dalam sekolah dan keluarga.

Pengarang menggunakan plot lengkap yang bertujuan untuk memberikan keputusan diakhir cerita tentang konflik yang dihadapi oleh semua tokohnya. Keputusan diakhir cerita berupa amanat yang disampikan pengaran untuk pembaca maupun untuk diri pengarang sendiri. Namun, ada beberapa pengarang yang tidak menggunakan plot lengkap karena pengarang sulit mengambil keputusan pada akhir cerita. Hal ini disebabkan karena pengarang masih remaja sehingga terdapat kebingungan dalam mengambil keputusan pada naskah drama yang ditulis.

Karakteristik latar dalam naskah drama serial bertema cinta tanah air karya siswa ekstrakulikuler SMAN 4 Malang menggunakan lingkungan sekolah dan rumah sebagai latar ceita. Pengarang menggunakan latar tersebut sesuai dengan kehidupan sehari-hari pengarang yang banyak menghabiskan waktu di sekolah dan di rumah. Pengarang masih belum memberikan variasi pembangan latar dalam naskah drama karena terfokus dengan lingkungan sehariharinya. Kesulitan pengarang dalam mengambangkan latar disebabkan karena kurangnya referensi pengarang dalam menulis naskah drama.

Pemilihan tema yang digunakan oleh pengarang berdasarkan batasan yang diberikan peneliti. Hal ini sesuai dengan tujuan peneliti untuk meningkatkan rasa cinta tanah air dalam lingkungan pendidikan melalui naskah drama. Pengarang memiliki keterbatasan dalam mengembangkan tema karena ini merupakan hal baru bagi pengarang. Menulis drama serial dengan tema cinta tanah air belum pernah dilakukan oleh pengarang dalam pembelajaran di kelas maupun saat kegiatan ektrakulikuler. Hal ini menjadi tantangan tersendiri bagi pengarang untuk bisa menyelesaikan naskah drama. Tema sosial yang digunakan sesuai dengan konflik yang terdapat dalam naskah drama yang berhubungan dengan lingkungan sosial tokoh.
Amanat yang ingin disampaikan oleh pengarang tentang mencintai budaya Indonesia dan sebagai generasi muda wajib untuk melestarikan warisan leluhur tersebut, selain itu untuk menanamkan sifat cinta tanah air kepada generasi muda.

Penggunaan dialog dalam naskah drama serial karya siswa menggunakan dialog umum dengan bahasa sehari-hari. Pengarang menggunakan bahasa Indonesia bertujuan untuk mempermudah aktor saat melakukan interaksi dengan tokoh lain. Pada beberapa naskah drama pengarang menyisipkan bahasa daerah di dalam dialog yang digunakan terutama dialek Malangan. Tujuan pengarang menggunakan dialog daerah dengan dialek Malangan untuk memperkenalkan bahasa daerahnya pada pembaca di luar daerah. Pengarang memiliki kebebasan bahasa yang akan digunakan dalam naskah dramanya.

Petunjuk laku yang digunakan menggunakan petunjuk lakuan tokoh. Penggunaan petunjuk laku lebih mudah digunakan dalam naskah drama karena pengarang bisa mengarahkan tokoh melalui gambaran adegan yang sudah disusun dalam cerita.

\section{REFERENSI}

Lutter, E. (2010). Kunci Sukses Menuis Skenario. Jakarta: Grasindo.

Noorfitriana, Yunita (2016). Karakteristik Naskah Drama Karya Siswa Kelas XI Bahasa Di SMAN 1 Grati. Skripsi tidak diterbitkan. Malang:UM

Pratiwi dan Siswiyanti, Y (2014). Teori Drama dan Pembelajarannya. Yogyakarta: Ombak Dua.

Priyatno, Joko .2010. Peningkatan Keterampilan Menulis Naskah Drama Melalui Media Lagu Dengan Menggunakan Pendekatan Kooperatif Learning Model "Numbered Heads Together" Siswa Kelas VIII SMPN 2 Tengaran. Skripsi diterbitkan. Semarang: UNNES. Diakses 05 November 2020.

Permendiknas 22 Th 2006 tentang Standar Isi.

Rokhmansyah, A. 2014. Studi dan Pengkajian Sastra: Perkenalan Awal Terhadap Ilmu Sastra. Yogyakarta: Graha Ilmu.

Solihuddin. 2013. Peningkatan Keterampilan Menulis Naskah Drama Satu Babak Dengan Teknik Picture and Picture 
Volume 6 No. 1 METALINGUA

April 2021 Jurnal Pendidikan Bahasa dan Sastra Indonesia

Melalui Media Gambar Gunung Pada Siswa Kelas VII B MTs Manbaul Ilmin Nafi Gunung Mulyo Kecamatan Sarang Kabupaten Rembang Tahun Pelajaran 2012/2013. Skripsi tidak diterbitkan: Semarang: UNNES

Universitas Negeri Malang, 2017, Pedoman Menulis Karya Ilmiah, Malang, Press (UM)

Yonny, A .2013. Sosiolinguistik. Yogyakarta: Pustaka Pelajar.

Waluyo, H. 2003. Drama: Teori dan Pengajarannya. Yogyakarta: Hanindita Graha Widia. 